\title{
Some Morphometric Relationships of Wels Catfish (Silurus glanis L., 1758) Inhabiting Sıddıklı Dam Lake (Kırşehir, Turkey)
}

\author{
Ramazan YAZICI ${ }^{1 *} \quad$ Okan YAZICIOĞLU ${ }^{2}$ \\ ${ }^{I}$ Laborant and Veterinary Health Program, Veterinary Department, Çiçekdağı Vocational School, Kırşehir Ahi Evran University, Kırşehir, Turkey \\ ${ }^{2}$ Department of Plant and Animal Production, Vocational School of Technical Sciences, Kırşehir Ahi Evran University, Kırşehir, Turkey
}

How to cite: Yazici, R. \& Yazicioğlu, O. (2020). Some Morphometric Relationships of Wels Catfish (Silurus glanis L., 1758) Inhabiting Sıddıklı Dam Lake (Kırşehir, Turkey). J. Anatolian Env. and Anim. Sciences, 5(2), 199 -204.

Atıf yapmak için: Yazici, R. \& Yazicioğlu, O. (2020). Sıddıklı Baraj Gölü (Kırşehir, Türkiye)'nde Yaşayan Yayın Balığı (Silurus glanis L., 1758)'nın Bazı Morfometrik İlişkileri. Anadolu Çev. ve Hay. Dergisi, 5(2), 199 -204.

: https://orcid.org/0000-0003-2274-0707 : https://orcid.org/0000-0003-4302-2181
*Corresponding author's: Ramazan YAZICI

Laborant and Veterinary Health Program, Veterinary Department, Çiçekdağı Vocational School, Kırșehir Ahi Evran University, Kırsehir, Turkey,ADRESS

$\triangle:$ rmznyzci@gmail.com

Mobile telephone : +90 (541) 7177573

Telephone $\quad:+90(386) 2805510$

Fax : $+90(386) 2804040$

\begin{abstract}
This study aims to investigate the relationships among morphometric characters of Wels catfish with total length and find the best model to assess relationships. A total of 198 fish samples was caught in Siddıklı Dam Lake between September 2015 and August 2016 in this study. The morphometric measures taken were: Total length (TL), Anal fin length (AFL), pectoral fin rays length (PFRL), body height (BH), head length (HL), and head height $(\mathrm{HH})$. No significant differences were noted between the pectoral fin rays (PFRL) of females and males, while the significant differences were observed in the other morphometric measurements (TL, AFL, BH, $\mathrm{HL}$, and $\mathrm{HH}$ ) of females and males. The linear and non-linear model were used to determine relationships between morphometric characters and total length. The linear model is the best fit for all relationships, so this model is preferred for all calculates. All relationships were highly significant $\left(\mathrm{P}<0.001, \mathrm{r}^{2}>0.81\right)$ and the mean percent prediction errors were less than $10 \%$. We found that AFL, PFRL, BH, HL, and $\mathrm{HH}$ are a good indicator for fish total length and are important for determining the length of Wels catfish. However, the best model was the relationship between anal fin length and total length for estimation of fish length in males and females. The data of the study provides novel information on relationships between morphometric characters for Wels catfish.
\end{abstract}

Keywords: Linear relationships, morphometric characters, S1ddıklı dam lake, wels catfish.

\section{Sıddıklı Baraj Gölü (Kırşehir, Türkiye)'nde Yaşayan Yayın Balığı (Silurus glanis L., 1758)'nın Bazı Morfometrik İlişkileri}

*Sorumlu yazar:

Ramazan YAZICI

Laborant ve Veteriner Sağlık Programı,

Veterinerlik Bölümü, Çiçekdağı Meslek

Yüksekokulu, Kırşehir Ahi Evran

Üniversitesi, Kırşehir, Turkiye

凶: rmznyzci@gmail.com

Cep telefonu : +90(541) 7177573

Telefon : $\quad+90(386) 2805510$

Faks $\quad:+90(386) 2804040$
Öz: Bu çalışmada yayın balığının morfometrik karakterleri ile total boyu arasındaki ilişkileri araştırmak ve ilişkileri değerlendirmek için en iyi modeli bulmak amaçlanmıştır. Bu çalışmada, Eylül 2015 ile Ağustos 2016 yılları arasında Sıddıklı Baraj Gölü'nde toplam 198 balık örneği yakalanmıştır. Alınan morfometrik ölçüler şunlardır: total boy (TL), anal yüzgeç uzunluğu (AFL), pectoral yüzgeç uzunluğu (PFRL), vücut yüksekliği $(\mathrm{BH})$, kafa uzunluğu (HL) ve kafa yüksekliği (HH). 'Dişi ve erkeklerin pektoral yüzgeç 1şınları (PFRL) arasında anlamlı bir fark gözlenmezken, diğer morfometrik ölçümlerde (TL, AFL, BH, HL ve HH) anlamlı farklılıklar tespit edilmiştir. Morfometrik karakterler ile total boy arasındaki ilişkileri belirlemek için doğrusal ve doğrusal olmayan modeller kullanılmıştır. Doğrusal modelin tüm ilişkiler için en uygun olduğu belirlenmiştir. Bu nedenle bu model tüm hesaplamalar için tercih edilmiştir. Tüm ilişkiler yüksek derecede anlamlı olup $(\mathrm{P}<0.001, \mathrm{r} 2>0.81)$ ortalama yüzde tahmin hatalarının \% 10 'dan daha az olduğu saptanmıştır. AFL, PFRL, BH, HL ve HH'nin balık total boyunun iyi bir göstergesi olduğu ve yayın balığı boyunu belirlemek için önemli olduğu tespit edilmiştir. Ancak, erkek ve dişilerde balık boyunun tahmini için en iyi model anal yüzgeç uzunluğu ile total boy arasındaki ilişkidir. Çalışmanın verileri, yayın balığı için morfometrik karakterler arasındaki ilişkiler hakkında yeni bilgiler sunmaktadır. 


\section{INTRODUCTION}

One of the major keys in fish biology study is morphometric characters since these characters use to understanding taxonomy and anatomy (Ünlü et al., 2012), growth variability (Jawad \& Al-Janabi, 2016), sexual differences (Gogoi \& Goswami, 2015), and stock status (Alhassan et al., 2015) of fish. In general, morphological features were indicated diversity both within and between fish populations. Morphometric characters considered as measurable structures and are characters describing different external body parts of fish. These characters commonly used in fish biology studies to measure discreteness between different fish stocks (Qadri et al., 2017), and to detect phylogeny of the fish population (Turan, 2004).

The morphometric relationships between different body characters of fish can be used to assess the well-being of individuals and to determine possible differences between separate unit stocks of the same species (King, 2007). The relationships between morphometric characters can be a tool to estimate back-calculate fish length from morphometric characters (Bostanc1 et al., 2014). Morphometry studies covered these relationships provide important information in the fish biology field including species diet, feeding behavior, ecological strategies, niche partitioning, habitat use and trophic structure.

The objectives of this study are to: i: reveal equations of relationships between morphometric characters and fish length, ii: test the accuracy of the back-calculated lengths using predictive equations. Moreover, this manuscript ensures the first information on the morphometrics relationships of Silurus glanis.

\section{MATERIAL AND METHODS}

Siddıklı Dam Lake located near $40 \mathrm{~km}$ west of Kırşehir province was built for irrigation purposes. The volume of Siddıklı Dam Lake is $28.5 \mathrm{hm}^{3}$, surface area is $1.65 \mathrm{~km}^{2}$, body height is $53 \mathrm{~m}$ and was completed in 1998 . It was put into operation in 2009 (Yazıc1, 2018).

A total of 198 fish samples collected between September 2015 and August 2016 in Siddıklı Dam Lake were examined for analyzing relationships between some measurable morphometric characters and fish length. Samples were caught by using gills nets with a mesh size ranging from 17 to $35 \mathrm{~mm} 50 \mathrm{~m}$ long and 40 to $80 \mathrm{~mm} \mathrm{100m}$ long. The six measurements of the morphometric characters were given in Table 1. The total length (TL) of each fish specimens were measured with approximately $0.1 \mathrm{~cm}$ precision. The morphometric characters were taken by using a digital caliper. The sex of samples was detected by the examination of gonads macroscopically.

Table 1. Definitions of morphometric measurements of Wels catfish in Siddıklı Dam Lake.

\begin{tabular}{lcl}
\hline Morphometric character & Abbreviation & \multicolumn{1}{c}{ Description on Fish } \\
\hline Total length & TL & from tip of snout to the end of the caudal fin \\
Anal fin length & AFL & distance measured in a straight line between the anterior most and posterior most junctions with the body. \\
Pectoral fin rays length & PFRL & the length of the longest find ray of pectoral fin. \\
Body height & BH & maximum depth of body \\
Head length & HL & the length from the nostril tip of nose to the back end of the opercular bone. \\
Head height & HH & distance along the broadest part of the head in ventral position. \\
\hline
\end{tabular}

Linear $(y=a+b x)$ and non-linear $\left(y=a * x^{b}\right)$ regression equations were used to determine what equations best described the relationships between morphometric characters and fish length. The model with the highest coefficient of determination $\left(r^{2}\right)$ was chosen to describe these relationships. Where ' $y$ ' is the dependent variable, ' $x$ ' is the independent variable, ' $a$ ' is a constant (intercept) and ' $b$ ' the regression coefficient (slope). The mean percent prediction errors for each regression were determined averaging the percent prediction error calculated for each observation. The percent prediction error (\% PE) for an individual is computed by the following formula (Scharf et al., 1998):

$$
\% P E=\frac{\mid \text { Observed }- \text { Predicted } \mid}{\text { Predicted }} \times 100
$$

The t-test was used to compare the outcomes of morphometric measurements between sexes. Paired t-test was used for determining the difference in measurements of left and right pectoral fin rays length. Differences between coefficients of regressions generated separately for females and males were tested by analysis of covariance (ANCOVA) (Zar, 1999). All data were analyzed using the Minitab 17 software program. All the statistical analyses were considered at the significance level of $5 \%(\mathrm{P}<0.05)$.

\section{RESULTS}

A total of 198 (female $=98$, male $=100)$ samples were analyzed for morphometric relationships. However, a total of 171 (female $=78$, male $=93$ ) Wels catfish samples were used for the relationship between pectoral fin rays length (PFRL) and total length (TL) owing to damaged and lost pectoral fin rays. 
The descriptive statistics of fish length (TL) and measurable morphometric characters (AFL, BH, HL, and $\mathrm{HH}$ ) are given in Table 2. The significant differences were observed in the morphometric measurements (TL, AFL, BH, $\mathrm{HL}$, and $\mathrm{HH}$ ) of females and males (t-test, $\mathrm{p}<0.05$, Table 2). Hence, regressions were generated separately according to both sexes (Figure 1). No significant differences were determined between the slopes " $b$ " of TL-AFL, TL-BH, TL$\mathrm{HL}$, and TL-HH relationships in females and males (ANCOVA, p>0.05).

Table 2. The descriptive statistics of fish total length (TL, cm), anal fin length $(\mathrm{AFL}, \mathrm{cm})$, body height $(\mathrm{BH}, \mathrm{cm})$, head length $(\mathrm{HL}, \mathrm{cm})$ and head height $(\mathrm{HH}, \mathrm{cm})$ of Wels catfish sampled from Siddıkl Dam Lake.

\begin{tabular}{llllll}
\hline Variable & Sex & \multicolumn{1}{c}{ n } & \multicolumn{1}{c}{ Mean \pm Sd } & \multicolumn{1}{c}{ Min-Max } & t-test \\
\hline \multirow{2}{*}{ TL } & Female & 98 & $55.76 \pm 13.11$ & $21.80-107.50$ & $\mathrm{p}<0.05$ \\
& Male & 100 & $60.33 \pm 16.79$ & $20.10-151.60$ & \\
AFL & Female & 98 & $30.54 \pm 6.96$ & $11.90-56.10$ & $\mathrm{p}<0.05$ \\
& Male & 100 & $33.55 \pm 9.10$ & $11.00-83.80$ & \\
$\mathrm{BH}$ & Female & 98 & $8.36 \pm 2.56$ & $2.60-22.40$ & $\mathrm{p}<0.05$ \\
& Male & 100 & $9.17 \pm 3.33$ & $2.10-29.40$ & \\
$\mathrm{HL}$ & Female & 98 & $10.28 \pm 2.71$ & $4.00-20.50$ & $\mathrm{p}<0.05$ \\
& Male & 100 & $11.23 \pm 3.43$ & $3.80-31.80$ & \\
$\mathrm{HH}$ & Female & 98 & $4.25 \pm 1.26$ & $1.10-8.70$ & $\mathrm{p}<0.05$ \\
& Male & 100 & $4.66 \pm 1.52$ & $1.10-14.20$ & \\
\hline
\end{tabular}
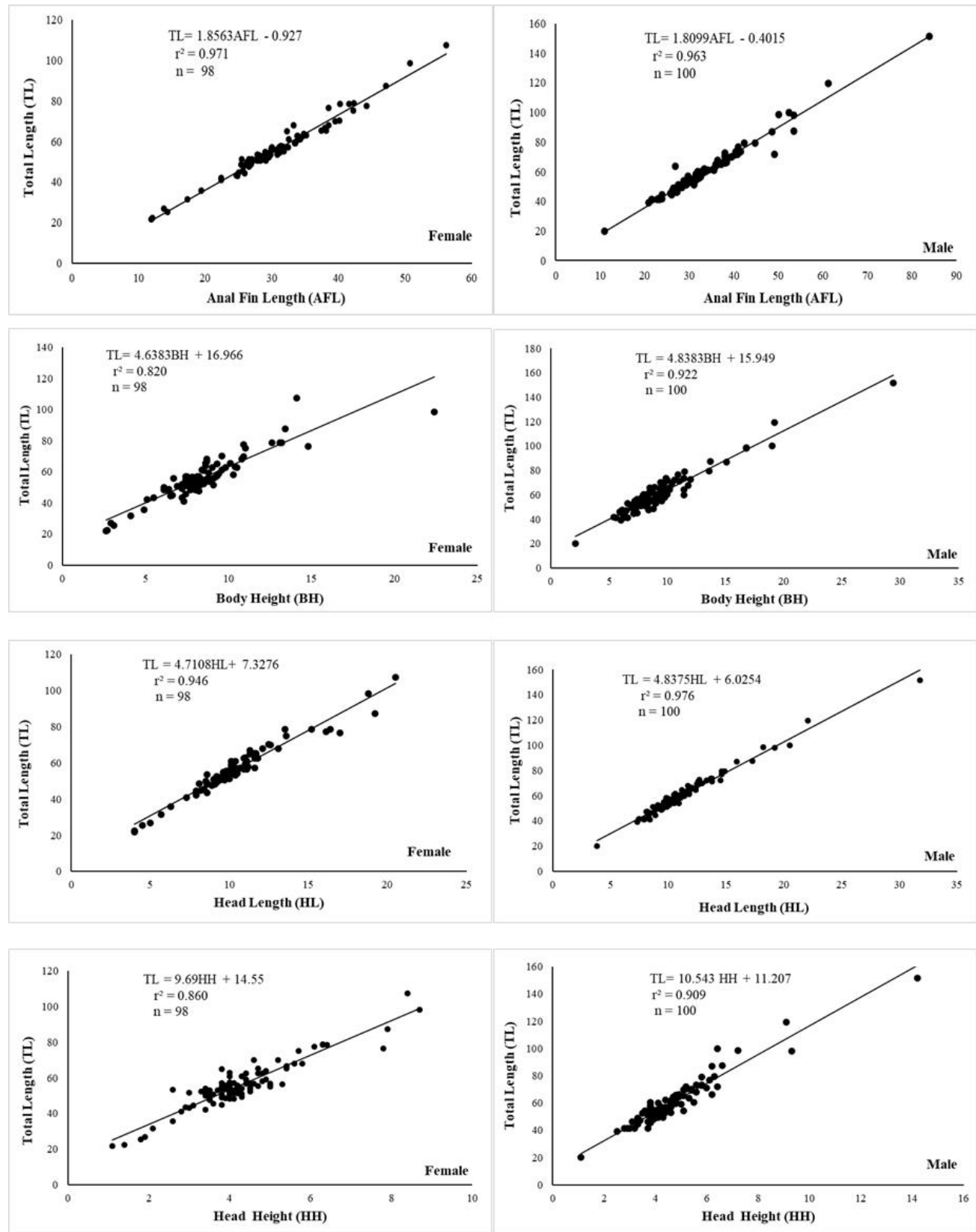

Figure 1. The relationships between morphometric characters and total length in females and males of Wels catfish.

The descriptive statistics of fish length (TL) and pectoral fin rays length (PFRL) are summarized in Table 3.
There was no significant difference between the right and left pectoral fin ray length (paired t-test, p>0.05) (Table 3). 
Table 3. The descriptive statistics of fish total length (TL, $\mathrm{cm}$ ) and pectoral fin rays length $(\mathrm{PFRL}, \mathrm{cm})$ of Wels catfish sampled from Siddiklı Dam Lake.

\begin{tabular}{llllll}
\hline Variable & Sex & n & \multicolumn{1}{c}{ Mean \pm Sd } & \multicolumn{1}{c}{ Min-Max } & t-test \\
\hline \multirow{3}{*}{ TL } & Female & 78 & $57.11 \pm 13.74$ & $21.80-107.50$ & \multirow{2}{*}{$>0.05$} \\
& Male & 93 & $59.80 \pm 14.21$ & $20.10-119.50$ & $\mathrm{p}>0.10-119.50$ \\
& Total & 171 & $58.57 \pm 14.02$ & $20.10-8.40$ & \\
\multirow{2}{*}{ PFRL } & Female & 78 & $4.08 \pm 1.19$ & $1.10-8.40$ & $\mathrm{p}>0.05$ \\
& Male & 93 & $4.25 \pm 1.18$ & $1.00-9.10$ & \\
& Total & 171 & $4.17 \pm 1.18$ & $1.00-9.10$ & \\
\hline
\end{tabular}

Therefore, the right pectoral fin rays lengths were chosen for the generation of regression equations. No significant difference was also observed in the pectoral fin rays length between females and males (t-test, $\mathrm{p}>0.05$ ). Therefore, the variables were pooled for further analysis (Figure 2).

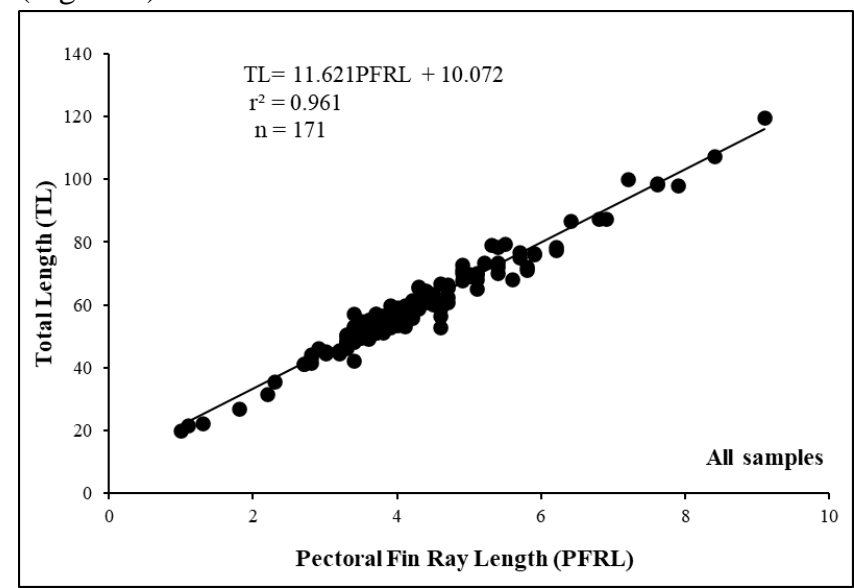

Figure 2. The relationship between pectoral fin ray length and total length in all samples.
The coefficient $\left(\mathrm{r}^{2}\right)$ of linear relationships was higher than non-linear relationships. The linear regression model provided the best fit for all relationships. For this reason, linear relationships were established for morphometric analysis. The mean values of all morphometric characters in male individuals were higher than females (Table 2 and 3). The coefficients $\left(r^{2}\right)$ of all linear regressions in males were calculated as higher than females, except anal fin length (AFL) (Figure 1). All regression analyses were highly significant $(\mathrm{P}<0.001)$ and analysis of morphometric characters versus TL indicated that the regression models explained more than $82 \%$ of the variance (Figure 1). Morphometric characters of Wels catfish were positively relevant to fish length, with $\mathrm{r}^{2}$ values ranging between 0.820 and 0.977 . According to sex, the best fit relationships were found between AFL-TL, and HL-TL among all morphometric characters. The fish total length (TL) was determined as approximately 1.81 times (TL/AFL) of anal fin length for the entire sample.

The mean percent prediction errors ranged from 2.941 to 7.216. The anal fin length (AFL) had the lowest value of mean \%PE in females, while head width $(\mathrm{HH})$ had the highest value of mean \%PE in females (Table 4). The regression with high $\mathrm{r}^{2}$ yielded had the lowest mean \% PE values (Table 4). For all morphometric characters, there was no significant difference between observed and predicted TL values in both females (t-test; $\mathrm{p}>0.05)$ and males (t-test; $\mathrm{p}>0.05)$.

Table 4. The mean percent prediction error (\%PE) values for morphometric characters in S. glanis from Siddıklı Dam Lake.

\begin{tabular}{|c|c|c|c|c|c|c|c|c|}
\hline \multirow{2}{*}{ Variable } & \multirow{2}{*}{ Sex } & \multirow{2}{*}{$\mathrm{n}$} & \multicolumn{2}{|c|}{ Observed TL $(\mathrm{cm})$} & \multicolumn{2}{|c|}{ Predicted TL $(\mathrm{cm})$} & \multicolumn{2}{|c|}{$\% \mathrm{PE}$} \\
\hline & & & Range & Mean \pm SD & Range & $\operatorname{Mean} \pm$ SD & Range & Mean \pm SD \\
\hline \multirow{2}{*}{ AFL } & Female & 98 & $21.80-107.50$ & $55.76 \pm 13.11$ & $21.16-103.21$ & $55.76 \pm 12.92$ & $0.011-12.187$ & $2.941 \pm 2.374$ \\
\hline & Male & 100 & $20.10-151.60$ & $60.33 \pm 16.79$ & $19.51-151.27$ & $60.33 \pm 16.48$ & $0.018-32.214$ & $2.960 \pm 3.952$ \\
\hline \multirow{2}{*}{$\mathrm{BH}$} & Female & 98 & $21.80-107.50$ & $55.76 \pm 13.11$ & $29.03-120.86$ & $55.76 \pm 11.88$ & $0.000-30.515$ & $7.048 \pm 5.971$ \\
\hline & Male & 100 & $20.10-151.60$ & $60.33 \pm 16.79$ & $26.11-158.20$ & $60.33 \pm 16.12$ & $0.152-23.016$ & $6.290 \pm 4.771$ \\
\hline \multirow{2}{*}{ HL } & Female & 98 & $21.80-107.50$ & $55.76 \pm 13.11$ & $26.17-103.90$ & $55.76 \pm 12.76$ & $0.012-16.701$ & $3.886 \pm 3.657$ \\
\hline & Male & 100 & $20.10-151.60$ & $60.33 \pm 16.79$ & 24.41-159.86 & $60.33 \pm 16.59$ & $0.009-17.650$ & $3.433 \pm 3.657$ \\
\hline \multirow{2}{*}{$\mathrm{HH}$} & Female & 98 & $21.80-107.50$ & $55.76 \pm 13.11$ & $25.21-98.85$ & $55.76 \pm 12.16$ & $0.087-34.360$ & $7.216 \pm 6.041$ \\
\hline & Male & 100 & $20.10-151.60$ & $60.33 \pm 16.79$ & $22.80-160.92$ & $60.33 \pm 16.01$ & $0.113-27.094$ & $5.894 \pm 4.745$ \\
\hline PFRL & Total & 171 & $20.10-119.50$ & $58.57 \pm 14.02$ & $21.69-115.82$ & $58.57 \pm 13.74$ & $0.009-16.730$ & $3.606 \pm 3.151$ \\
\hline
\end{tabular}

\section{DISCUSSION}

There were several researches on the age (Y1lmaz et al. 2007; Saylar, 2009; Alp et al., 2011; Saylar, 2014), growth (Carol et al., 2009; Copp et al., 2009; Uysal et al., 2009; Alp et al., 2011), reproduction (Yazic1 et al., 2018), morphological characters (Ünlü et al., 2012), and the diet (Czarnecki et al., 2003; Bora \& Gul, 2004; Alp, 2017) of Wels catfish. However, no studies were conducted on the morphometric biometry of this species. Therefore, this study presents the first data on this subject in Wels catfish.

Generally, linear functions are preferred and mostly used to determine the relationship between body dimensions and length of the fish (Begum et al., 2008; Šantić et al., 2011; Jawad \& Al-Janabi, 2016). In this study, both linear and non-linear models were analyzed for defining the relationships between morphometric variables and fish length. Linear model was provided higher regression coefficient than non-linear model for all relationships. Consequently, linear model was preferred for our analysis. Similarly, these relationships in many previous studies were also defined using this model for various fish species (Hajjej et al., 2011; Keč \& Zorica, 2011; Balai et al., 2017).

One of the major keys in fish biology is morphometric characters since morphometric analysis 
included these characters plays a key role to estimate relationships among various body parts. Morphometric characters in female and male may not be provide the same result in back-calculation of fish length (Begum et al., 2008). In current study, results of testing the difference between the measurements of morphometric characters in females and males showed significant difference. Thus, the regressions were generated separately according to both sexes. These results agree with results of other studies (Begum et al., 2008; Amin et al., 2014; Yilmaz et al., 2014). On the other hand, there were no sexual differences in relationships between pectoral fin length and total length. So, the measurements of males and females were pooled to calculate this relationship.

Differences in the measurement data of same body parts mostly depend on the fish samples quality. Damages as morphological can be seen in fish (e.g. lost or damaged body part such as anal fin, tail, and body length). This status may make measurements difficult. Measurements from intact body parts can be used to calculate length of other body parts. The results of study suggested that the all morphometric relationships are well suited to the prediction of fish length. Among relationships, the anal fin length and head length measurements are important for determining the total length of Wels catfish.

In conclusions, the results of current study show that there are difference morphometric characters in males and females. This situation may indicate that there is a difference in the growth of the characters mentioned in the female and male. The distinction between male and female is important for fisheries management, stock assessment, paleontological studies, population dynamics, and growth parameters. Furthermore, this study provides the first data on relationships between morphometric characters and total length in Wels catfish. These relationships are a helpful tool in predicting fish total length from morphometric characters and useful for studies on food and feeding, prey-predator relationships, as well as for paleontological studies.

\section{REFERENCES}

Alhassan, E.H., Akongyuure, D.A. \& Asumang, F. (2015). Determination of morphometric relationship and condition factors of four Cichlids from Golinga reservoir in northern region of Ghana. OnLine Journal of Biological Sciences, 15(3), 201-206. DOI: 10.3844/ojbsci.2015.201.206.

Alp, A., Kara, C., Üçkardeş, F., Carol, J. \& GarcíaBerthou, E. (2011). Age and growth of the European catfish (Silurus glanis) in a Turkish Reservoir and comparison with introduced populations. Reviews in Fish Biology and
Fisheries, 21(2), 283-294. DOI: 10.1007/s11160010-9168-4.

Alp, A. (2017). Diet Shift and Prey Selection of the Native European Catfish, Silurus glanis, in a Turkish Reservoir. Journal of Limnology and Freshwater Fisheries Research, 3(1), 15-23. DOI: 10.17216/limnofish.288217.

Amin, M.R., Mollah, M.F. \& Taslima, K. (2014). Morphological observation and length-weight relationship of critically endangered riverine catfish Rita rita (Hamilton). Pakistan Journal of Biological Sciences, 17(2), 234-240. DOI: 10.3923/pjbs.2014.234.240

Balai, V.K., Sharma, L.L. \& Ujjania, N.C. (2017). Morphometric relationship of Indian major carps (Catla catla, Labeo rohita and Cirrhinus mrigala) form Jaisamand Lake, Udaipur (India). Journal of Entomology and Zoology Studies, 5(3), 547-550.

Begum, M., Al-Mamun, A., Islam, M.L. \& Alam, M.J. (2008). Morphometric characters and their relationship in estuarine catfish. Journal of the Bangladesh Agricultural University, 6(2), 349353.

Bora, N.D. \& Gül, A. (2004). Feeding biology of Silurus glanis (L., 1758) living in Hirfanlı Dam Lake. Turkish Journal of Veterinary and Animal Sciences, 28(3), 471-479.

Bostancı, D., Yağcı, M., Kontaş, S., Kurucu, G. \& Polat, N. (2014). İstilacı Bir Tür Atherina boyeri Risso, 1810'nin Eğirdir Gölü Popülasyonunda Morfometrik ve Bazı Kemiksi Yapıların Biyometrik Özellikleri. Süleyman Demirel Üniversitesi Eğirdir Su Ürünleri Fakültesi Dergisi, 10(1), 1-11. DOI: 10.22392/egirdir.246375.

Carol, J., Benejam, L., Benito, J. \& García-Berthou, E. (2009). Growth and diet of European catfish (Silurus glanis) in early and late invasion stages. Fundamental and Applied Limnology, 174(4), 317-328. DOI: 10.1127/1863-9135/2009/0174-0317.

Copp, G.H., Robert Britton, J., Cucherousset, J., García-Berthou, E., Kirk, R., Peeler, E. \& Stakènas, S. (2009). Voracious invader or benign feline? A review of the environmental biology of European catfish Silurus glanis in its native and introduced ranges. Fish and fisheries, 10(3), 252282. DOI: $10.1111 /$ j.1467-2979.2008.00321.x

Czarnecki, M., Andrzejewski, W. \& Mastyñski, J. (2003). The feeding selectivity of wels (Silurus glanis L.) in Lake Góreckie. Archives of Polish Fisheries, 11(1), 141-147.

Gogoi, R. \& Goswami, U.C. (2015). Morphometric and meristic study of Amblypharyngodon mola (Ham- 
Buch) from different habitats of Assam. Annals of Biological Research, 6(2), 10-14.

Hajjej, G., Hattour, A., Allaya, H., Jarboui, O., Mourad, C. \& Bouain, A. (2011). Biometry, Length-length and Length-weight relationships of little tunny Euthynnus alletteratus in the Tunisian Waters. Journal of Fisheries and Aquatic Science, 6(3), 256-263. DOI: 10.3923/jfas.2011.256.263.

Jawad, L.A. \& Al-janabi, M.I. (2016). Morphometric characteristics of catfish Silurus triostegus heckel, 1843 from the tigris and shatt al-arab rivers, IRAQ. Croatian Journal of Fisheries, 74(4), 179185.

Keč, V.Č. \& Zorica, B. (2011). Biometry markers of chub mackerel, Scomber japonicus Houttuyn, 1782, in the Adriatic Sea. Acta Adriatica, 52(2), 215-222.

King, M. (2007). Fisheries biology, assessment and management. Second Edition. Blackwell Scientific Publications, Oxford: 1-381.

Qadri, S., Shah, T.H., Balkhi, M.H., Bhat, B.A., Bhat, F.A., Najar, A.M. \& Alia, S. (2017). Morphometrics and length-weight relationship of Schizothorax curvifrons Heckel 1838 in River Jhelum, Kashmir, India. Indian Journal of Animal Research, 51(3), 453-458.

Saylar, Ö. (2009). Kabalar Göleti (Taşköprü/KastamonuTürkiye)'nde yaşayan yayın balığı (Silurus glanis L., 1758)'nın çeşitli oluşumları kullanılarak yaşının belirlenmesi. Kastamonu Üniversitesi Kastamonu Ĕgitim Dergisi, 2, 659-664.

Saylar, Ö. (2014). Comparative Age Determination Methods of Silurus glanis L., 1758 Living in Altınkaya Dam Lake According to Their Bony Structures. The Journal of Adyutayam, 2(2), 1-7.

Šantić, M., Rađa, B., Paladin, A. \& Čurić, A. (2011). Biometric properties of the European hake, Merluccius merluccius (Osteichthyes: Merlucciidae), from the central Adriatic Sea. Archives of Biological Sciences, 63(1), 259-267.

Scharf, F.S., Yetter, R.M., Summer, A.P. \& Juanes, F. (1998). Enhancing diet analyses of piscivorous fishes in the Northwest Atlantic through identification and reconstruction of original prey sizes from ingested remains. Fishery Bulletin, 96, 575-588.

Turan, C. (2004). Stock identification of Mediterranean horse mackerel (Trachurus mediterraneus) using morphometric and meristic characters. ICES Journal of Marine Science, 61, 774-781. DOI: 10.1016/j.icesjms.2004.05.001.

Ünlü, E., Değer, D. \& Cicek, T. (2012). Comparison of morphological and anatomical characters in two catfish species, Silurus triostegus Heckel, 1843 and Silurus glanis L., 1758 (Siluridae, Siluriformes). North-Western Journal of Zoology, 8(1), 119-124.

Uysal, R., Apaydın Yağci, M., Yeğen, V., Cesur, M., Yağci, A., Çetinkaya, S. \& Bostan, H. (2009). Growth Properties of European Catfish (Silurus glanis L., 1758) Population in İznik Lake (BursaTurkey). Journal of Natural and Applied Sciences, 13(3), 221-228.

Yazıcı, R. (2018). Biological properties of the Wels Catfish (Silurus glanis L., 1758) from Siddlkl Küçükboğaz Dam Lake. Kırşehir Ahi Evran University. Kırşehir, Turkey, 154p.

Yazıcı, R., Yılmaz, M. \& Yazıcıŏ̆lu O. (2018). Reproduction Properties of Wels Catfish (Silurus glanis, L., 1758) Inhabiting Siddıklı Reservoir. Journal of Limnology and Freshwater Fisheries Research, 4(2), 112-117. DOI: 10.17216/LimnoFish.415933.

Yılmaz, S., Yılmaz, M. \& Polat, N. (2007). Altınkaya Baraj Gölü (Samsun-Türkiye)'nde Yaşayan Yayın Balığı (Silurus glanis L., 1758)'nın Yaşı İçin Farklı Kemiksi Yapıların Değerlendirilmesi. Firat Üniversitesi, Fen ve Mühendislik Bilimleri Dergisi, 19(1), 7-11.

Yilmaz, S., Yazicioglu, O., Saygin, S. \& Polat, N. (2014). Relationships of otolith dimensions with body length of European perch, Perca fluviatilis L., 1758 from Lake Ladik, Turkey. Pakistan Journal of Zoology, 46(5), 1231-1238.

Zar, J.H. (1999). Biostatistical Analysis. 4th ed. Upper Saddle River, NJ, USA: Prentice Hall. 